\title{
Investigating Microbial Diversity and UV Radiation Impact at the High-Altitude Lake Aguas Calientes, Chile
}

\author{
Lorena Escudero, Guillermo Chong \\ Centro de Investigación Científica y Tecnológica para la Minería (CICITEM) \\ Cecilia Demergasso ${ }^{11}$ \\ (Centro de Biotecnología, Universidad Católica del Norte) \\ María Eugenia Farías \\ (PROIMI Planta Piloto de Procesos Industriales Microbiológicos. CONICET Consejo Nacional de \\ Investigaciones Científicas y Técnicas) \\ Nathalie A. Cabrol, Edmond Grin \\ (NASA Ames/SETI CSC)
}

Edwin Minkley, Jr., Youngeob Yu

(Carnegie Mellon University)

\begin{abstract}
The High-Lakes Project is funded by the NAI and explores the highest perennial volcanic lakes on Earth in the Bolivian and Chilean Andes, including several lakes $\sim 6,000 \mathrm{~m}$ elevation. These lakes represent an opportunity to study the evolution of microbial organisms in relatively shallow waters not providing substantial protection against UV radiation. Aguas Calientes $(5,870 \mathrm{~m}$ ) was investigated (November 2006) and samples of water and sediment collected at 1, 3, 5, and $10 \mathrm{~cm}$ depth. An Eldonet UV dosimeter positioned on the shore records UV radiation and temperature, and is logging data year round. A UV SolarLight sensor allowed acquisition of point measurements in all channels at the time of the sampling. UVA, UVB, and PAR peaks between 11:00 am and 1:00 pm reached $7.7 \mathrm{~mW} / \mathrm{cm}^{2}, 48.5 \mu \mathrm{W} / \mathrm{cm}^{2}$, and $511 \mathrm{~W} / \mathrm{m}^{2}$, respectively. The chemical composition of the water sample was analyzed. DNA was extracted and DGGE analyses with bacterial and archaeal $16 \mathrm{~S}$ fragments were performed to describe microbial diversity. Antibiotic resistances were established previously in similar environments in Argentine Andean wetlands. In order to determine these resistances in our samples, they were inoculated onto LB and R2A media and onto R2A medium containing either chloramphenicol, ampicillin or tetracycline. Bacterial was higher than archeal cell number determined by RT-PCR in all the samples, reaching maximum total values of $5 \times 10^{5}$ cell $\mathrm{mL}-1$. DGGE results from these samples and Licancabur summit lake $(5,916 \mathrm{~m})$ samples were also compared. Eight antibiotic-resistant Gram negative strains have been isolated with distinct resistance patterns.
\end{abstract}

Keywords: High altitude lakes, microbial diversity, UV resistance, antibiotic resistance

${ }^{1}$ cdemerga@ucn.cl DB Check, Prod Check, Notes: 


\section{INTRODUCTION}

We present data and results from an ongoing project of astrobiological high-altitude expeditions investigating the highest and least explored perennial volcanic lakes on Earth in the Bolivian and Chilean Andes ${ }^{1}$, including several nearing and beyond $6,000 \mathrm{~m}$ in elevation. Due to their extreme conditions, and pristine characteristics, these lakes are natural laboratories for studying microbial diversity and their connection with environmental factors like UV radiation, oligotrophy and metal content. They provide the field data missing beyond $4,400 \mathrm{~m}$ to complete our understanding of terrestrial lakes and biota. Research on the effects of UV has been performed in lower altitude lakes $\left.{ }^{\text {e.g., }},{ }^{3}\right)$. In addition, transparent water and high UV irradiance may maximize the penetration and effect of UV radiation ${ }^{4,5}$. These lakes represent an opportunity to observe the evolution of microorganisms in shallow waters that do not offer substantial UV protection. The main goal of that work is to identify the microbial community composition in Aguas Calientes (Fig. 1) and to test the UV and antibiotic resistances of some isolates to evaluate co-resistance mechanisms.

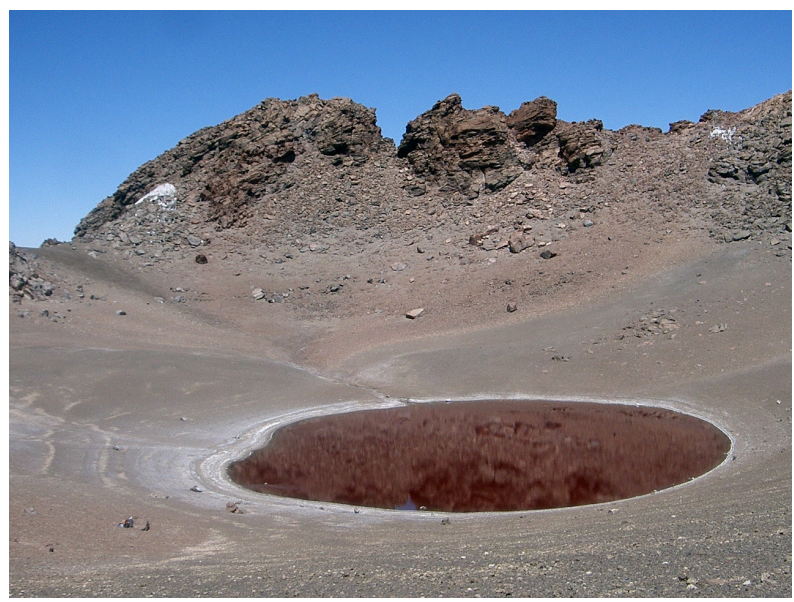

Figure 1. Laguna Aguas Calientes, 23.22'S, 67.41'W, 5870m, Northern Chile.

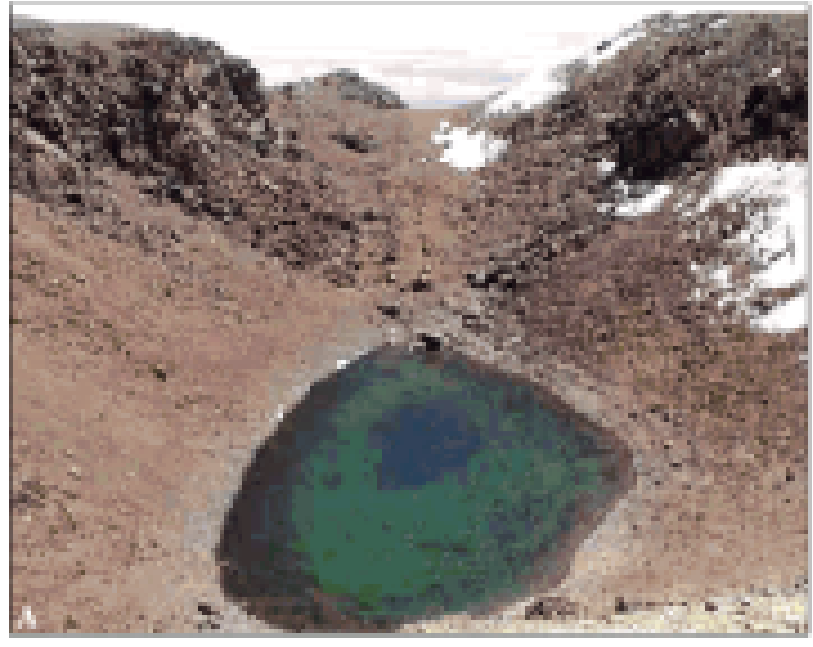

Figure 2. Licancabur Summit Lake photographed during the 2002 expedition from the crater rim, $22^{\circ} 50^{\prime} \mathrm{S}, 67^{\circ} 53^{\prime} \mathrm{W}, 5916 \mathrm{~m}$. 


\section{MATERIALS AND METHODS}

\subsection{Sampling and measurements}

Aguas Calientes $\left(23.22 \mathrm{~S}, 67.41^{\prime} \mathrm{W}, 5870 \mathrm{~m}\right)$ was investigated in November 2006 and a surface brine sample (AC-N $\left.{ }^{\circ} 1\right)$ and sediment collected at 1, 3, 5, and $10 \mathrm{~cm}$ depth (AC-1 cm, AC-3 cm, AC-5 cm and AC-10 cm, respectively). Water and sediment samples from the Licancabur summit lake $\left(22^{\circ} 50^{\prime} \mathrm{S}, 67^{\circ} 53^{\prime} \mathrm{W}, 5916 \mathrm{~m}\right)$ were collected during the 2002 and 2003 campaign performed in October ${ }^{6}$. All the samples were collected in sterile flasks and stored in between $5-10^{\circ} \mathrm{C}$ until further processing in the laboratory. The surface water samples from the Licancabur summit lake were collected following the same method. The chemical composition and physicochemical parameters of the water samples was analyzed in the laboratory using Inductively-Coupled Mass Spectrometry (ICPMS) and Ion Chromatography (IC). An Eldonet UV dosimeter positioned on the shore recorded UV radiation and temperature, and logged data year round. A UV SolarLight sensor allowed the acquisition of point measurements in all channels at the time of the sampling.

\subsection{Total DNA extraction and quantification}

DNA was extracted for $16 \mathrm{~S}$ rRNA analysis. Between 200 and $700 \mathrm{ml}$ of brine were filtered through $0.2 \mu \mathrm{m}$ polycarbonate membranes (Nuclepore) and stored at $-70^{\circ} \mathrm{C}$. Filters were incubated with lysozyme, proteinase $\mathrm{K}$ and sodium dodecyl sulfate (SDS) in lysis buffer as described previously ${ }^{7}$. DNA was extracted with a High Pure PCR Template Preparation Kit. From the sediments, nucleic acid was extracted from 20 and $25 \mathrm{~g}$ of sediments re-suspended in the $0,9 \% \mathrm{NaCl}$ solution and Tween $20 \%$.

\subsection{PCR amplifications and 16s rRNA analysis}

The extracted genomic DNA was used as the target in the PCR to amplify the bacterial and archaeal 16S rRNA genes with thermocycler (Eppendorf Mastercycler gradient). Bacterial $550 \mathrm{bp}$ and archaeal 624 fragments suitable for subsequent denaturing gradient gel electrophoresis (DGGE) analysis were obtained with the primer combination $358 \mathrm{f}$ with GC clamp plus $907 \mathrm{r}$ and $344 \mathrm{f}$ with GC clamp plus $915 \mathrm{r}$ respectively ${ }^{8-10}$. For nested PCR PARC21F-PARC1492R and fD2-rD2 were first used for archaeal and bacterial fragments respectively. These amplification products were then used as template in PCR as we describe above. A 6\% polyacrylamide gel with a gradient of DNA-denaturant agent was casted by mixing two stock solutions of acrylamide containing $40 \%$ and $80 \%$ denaturant agent, using a two chambers gradient maker (100\% denaturant agent is defined as $7 \mathrm{M}$ urea and $40 \%$ deionized formamide) from CBS DGGE-2000 system (CBS Scientific Company). The gradient was overlaid with nondenaturant acrylamide in order to obtain well polymerized slots. Around $800 \mathrm{ng}$ of PCR product was loaded for each sample (a maximum of 18 samples per gel) and the gels were run at $100 \mathrm{~V}$ and $60^{\circ} \mathrm{C}$ for $16 \mathrm{~h}$ for bacterial fragments and $250 \mathrm{~V}$ for $5 \mathrm{~h}$, in $1 \mathrm{x}$ TAE buffer $(40 \mathrm{mM}$ Tris base [pH 7.4], $20 \mathrm{mM}$ sodium acetate, $1 \mathrm{mM}$ EDTA). The gels were stained with the nucleic acid stain SybrGold for 30 min, rinsed with 1x TAE buffer, removed from the glassplate to a UV transparent gel scoop (Sigma) and visualized with UV light.

Bands were excised from the gels and re-amplified as reported ${ }^{11}$. PCR products were purified with the QIAquick PCRPurification Kit (QIAGEN) and quantified in an agarose gel. About 10 to $20 \mathrm{ng}$ were directly used for the sequencing reaction, using primer $358 \mathrm{f}$ without the GC-clamp. Sequences were sent to BLAST search (www.ncbi.nlm.nih.gov) to determine the closest relative in the database.

\subsection{Real Time PCR}

Real-time PCR was performed to quantify the 16S rRNA gene copies with cDNA target. Quantimix Easy SYG Kit (Biotools) was used with a machine Rotor-GeneTM 6200 (Corbett Research Pty Ltd). The reaction mixture contains 10 $\mu 1$ of SYBRB ${ }^{\circledR}$ Green PCR Master Mix (Biotools), $1 \mu \mathrm{l}$ of $\mathrm{cDNA}, 1 \mu \mathrm{l}$ of the universal primers for Bacteria and Archaea, and $\mathrm{H}_{2} \mathrm{O}$ added to a total of $20 \mu$ l.

\section{4-35 V. 8 (p.3 of 11) / Color: No / Format: Letter / Date: 9/18/2007 3:03:51 PM}




\subsection{Strain isolation and identification}

Bacteria were isolated by plating in solid Luria Bertani (LB) and R2A media and incubation at $28^{\circ} \mathrm{C}$. Colonies were grouped into morphologically different types. Isolated strains were cultured in LB broth with shaking at $25^{\circ} \mathrm{C}$. Genomic DNA extraction, 16S rDNA gene partial amplification and sequencing were carried out.

\subsection{Antimicrobial Susceptibility}

In order to determine the ATB resistances, the isolated strains were inoculated onto LB and R2A media containing either Amp (ampiciline) $10 \mathrm{~g}$, Em (Erythromicin) $15 \mathrm{~g}$, Clm (Chloram-phenicol) $30 \mathrm{~g}$ and Tc (Tetracicline) $30 \mathrm{~g}$. After 24 hour of incubation, at $28^{\circ} \mathrm{C}$, the bacterial colonies were counted. Tests were made by duplicate.

\subsection{UV-B irradiation}

In order to quantify the effect of UV on the strains, cells in mid log phase of growth were exposed to a UV-C lamp $(253.7 \mathrm{~nm}, 30 \mathrm{~W})$ in a plate. After $10,20,40,80$ and $120 \mathrm{~min}$ of exposure, $100 \mu \mathrm{L}$ of appropriate serial dilutions $\left(10^{-3}\right.$ to $10^{-6}$ ) were spread onto LB-agar plates $(9 \mathrm{~cm}$ in diameter) in duplicate and then incubated in the dark. The number of colony forming units (CFUs) was determined after $24 \mathrm{~h}$ of incubation at $28^{\circ} \mathrm{C}$ in the dark to prevent photoreactivation. Controls of unexposed samples were run simultaneously in darkness and calculations of the percentages of cell survival after each treatment were made relative to these controls. Results were expressed as percentage of survival, which indicate the percent of CFU counted in the irradiated samples versus the control without irradiation. $\mathrm{TE}_{8}$ indicate the radiation exposure required to inactivate $92 \%$ of a bacterial population. The $\mathrm{TE}_{8}$ values were calculated from the regression line of the exponential decrease of CFU with time. The $r^{2}$ of the regression is provided as an indication of the goodness of fit ${ }^{2}$.

\section{RESULTS AND DISCUSSION}

\subsection{Description of the studied environments}

Both sampled lakes are located in volcano-tectonic and hydrothermal settings. The radiation characteristics of the surveyed Aguas Calientes lake and the temperature measured during sample collection are described in Table 1. The UV flux measured in the Licancabur' summit lake in 2003 campaign reached $89 \mathrm{~W} / \mathrm{m}^{2}$.

Table 1. Radiation and temperature measures acquired near the lake Aguas Calientes (5870 m), November 28, 2006

\begin{tabular}{|c|c|c|c|c|}
\hline Time & $\begin{array}{l}\text { UVA } \\
(\mathrm{mW} / \mathrm{cm} 2)\end{array}$ & $\begin{array}{c}\text { UVB } \\
(\mu \mathrm{W} / \mathrm{cm} 2)\end{array}$ & $\begin{array}{l}\text { PAR } \\
(\mathrm{W} / \mathrm{m} 2)\end{array}$ & Temp. ( oC) \\
\hline $11: 00$ & 7 & 44.7 & 482 & -1 \\
\hline $12: 00$ & 7.526 & 49.5 & 509 & 2.3 \\
\hline $12: 30$ & 7.721 & 48.5 & 512 & 5.6 \\
\hline $12: 45$ & 7.715 & 48.5 & 511 & 6.2 \\
\hline $13: 00$ & 7.709 & 48.8 & 512 & 3.8 \\
\hline
\end{tabular}

The measured level of UVC is very small (not shown) because of the instrument specification.

ICP-MS results (Table 2) show that the Licancabur summit lake is enriched in some major rock forming elements: Na (67.5ppm), $\mathrm{Mg}(39.6 \mathrm{ppm}), \mathrm{Ca}(230 \mathrm{ppm}), \mathrm{Al}(1.75 \mathrm{ppm}), \mathrm{Fe}(0.902 \mathrm{ppm})$ compared with geothermal springs located at the base of Licancabur. In particular, Al is $>10$ times more abundant in the summit lake (a warm spring in LB has $[\mathrm{Al}]=0.00592 \mathrm{ppm})^{12}$. If we assume that the fluids from the springs and summit lake have a similar composition, then these differences may result from increased water rock interaction as the fluid flowing up to the summit is allowed more time to react with local lithologies. IC results show a similar trend, but more notably with respect to local meteoric 
waters (snowmelt analysis) ${ }^{12}$. Aguas Calientes water samples shows from 1.4 to 2.3 folds higher contents of most of these rock forming elements, and up to 20 folds higher $\mathrm{Al}$ content than Licancabur summit lake samples. As and $\mathrm{SO}_{4}{ }^{2-}$ contents are also higher. The pH of the Aguas Calientes water samples (4.9) may be the cause of higher rock dissolution.

Those results show the difference between those lakes located in volcano-tectonic and hydrothermal settings and other high altitude lakes where the microbial diversity in water and sediments have been recently studied in China ${ }^{13}, 14$. Hydrothermal settings lakes show an upper than 10 rate sulphate/chloride compared with evaporitic high altitude lakes with lower than 1 rate sulphate/chloride.

\subsection{Cell numbers by Real Time-PCR}

In both studied systems, cells numbers are higher for bacteria than for archaea in water samples. The results do not show an UV limited cell number distribution in Aguas Calientes like in Licancabur lake where the organic count increases with sediment depth ${ }^{12}$. In both sediment samples from Aguas Calientes the only microorganisms detected by Real Time PCR were archaeal cells in low content (Table 3). pH and higher ionic contents in Aguas Calientes may be the cause of lower cell numbers. Nevertheless, Nested-PCR used to perform DGGE analysis shows the presence of a limited bacterial population, also in sediment samples AC-1 and AC-5.

Table 2. Chemical analysis results from the brine sample AC- $\mathrm{N}^{\circ} 1$ of Aguas Calientes lake $(5,930 \mathrm{~m})$ and Licancabur summit lake (5914 m).

\begin{tabular}{llcc} 
Parameter & Units & AC-N $^{0} 1$ & LC \\
\hline $\mathrm{As}$ & $\mathrm{mg} / \mathrm{L}$ & 1,0 & 0,03 \\
$\mathrm{Ca}$ & $\mathrm{mg} / \mathrm{L}$ & 249 & 230,0 \\
$\mathrm{Mg}$ & $\mathrm{mg} / \mathrm{L}$ & 135 & 39,60 \\
$\mathrm{~N} 03-$ & $\mathrm{mg} / \mathrm{L}$ & 0,97 & 0,08 \\
$\mathrm{~K}$ & $\mathrm{mg} / \mathrm{L}$ & 14,8 & 26,20 \\
$\mathrm{Na}$ & $\mathrm{mg} / \mathrm{L}$ & 154 & 67,50 \\
$\mathrm{SO} 4^{-2}$ & $\mathrm{~g} / \mathrm{L}$ & 1,93 & 0,59 \\
$\mathrm{Cl}-$ & $\mathrm{mg} / \mathrm{L}$ & 131 & 57,79 \\
$\mathrm{Fe}$ & $\mathrm{mg} / \mathrm{L}$ & 1,24 & 0,90 \\
$\mathrm{Al}$ & $\mathrm{mg} / \mathrm{L}$ & 36 & 1,75 \\
$\mathrm{Co}$ & $\mathrm{mg} / \mathrm{L}$ & 0,19 & $\mathrm{ND}$ \\
$\mathrm{Cu}$ & $\mathrm{mg} / \mathrm{L}$ & 0,36 & $\mathrm{ND}$ \\
$\mathrm{Mn}$ & $\mathrm{mg} / \mathrm{L}$ & 3,94 & 0,04 \\
$\mathrm{Ni}$ & $\mathrm{mg} / \mathrm{L}$ & 0,36 & $\mathrm{ND}$ \\
$\mathrm{P}$ & $\mathrm{mg} / \mathrm{L}$ & 0,64 & $\mathrm{ND}$ \\
$\mathrm{Sr}$ & $\mathrm{mg} / \mathrm{L}$ & 0,29 & $\mathrm{ND}$ \\
$\mathrm{Zn}$ & $\mathrm{mg} / \mathrm{L}$ & 0,4 & $\mathrm{ND}$ \\
\hline
\end{tabular}


Table 3. Physicochemical characteristics and cell number by Real Time PCR

\begin{tabular}{|c|c|c|c|c|c|c|c|c|c|}
\hline \multirow[t]{2}{*}{ System } & \multirow[t]{2}{*}{ Date } & \multirow[t]{2}{*}{$\begin{array}{l}\text { Sample } \\
\text { Code }\end{array}$} & \multirow[t]{2}{*}{$\begin{array}{l}\text { Sample } \\
\text { type }\end{array}$} & \multirow[t]{2}{*}{$\mathrm{pH}$} & \multirow[t]{2}{*}{$\begin{array}{c}\text { Temperature } \\
{ }^{\circ} \mathrm{C}\end{array}$} & \multirow[t]{2}{*}{$\begin{array}{l}\mathrm{TDS} \\
\mathrm{mg} \mathrm{L}^{-1}\end{array}$} & \multirow{2}{*}{$\begin{array}{c}\text { DAPI } \\
\text { Cell count } \\
\text { Cells } \mathrm{mL}^{-1}\end{array}$} & \multicolumn{2}{|c|}{$\begin{array}{l}\text { 16S rRNA gene copy } \\
\mathrm{mL}^{-1}\end{array}$} \\
\hline & & & & & & & & Bacteria & Archaea \\
\hline \multirow{3}{*}{$\begin{array}{l}\text { Licancabur } \\
\text { Summit } \\
\text { Lake }\end{array}$} & \multirow{3}{*}{$\begin{array}{c}\text { 30-10-2002 } \\
\text { and } \\
04-11-2003\end{array}$} & LC-1 & water & \multirow[t]{3}{*}{8.5} & \multirow[t]{3}{*}{4.9} & \multirow[t]{3}{*}{1050} & $1.94 \mathrm{E}+06$ & $4,80 \mathrm{E}+04$ & $1,30 \mathrm{E}+02$ \\
\hline & & LC-2 & water & & & & $1.61 \mathrm{E}+06$ & $1,10 \mathrm{E}+04$ & $6,50 \mathrm{E}+02$ \\
\hline & & LC-2_05 & water & & & & & $1,20 \mathrm{E}+04$ & BDL \\
\hline \multirow{5}{*}{$\begin{array}{l}\text { Laguna } \\
\text { Aguas } \\
\text { Calientes }\end{array}$} & \multirow[t]{5}{*}{ 28-11-2006 } & AC-N¹ & water & \multirow[t]{5}{*}{4.7} & \multirow[t]{5}{*}{-1 to 6.2} & \multirow[t]{5}{*}{1240} & & $4,90 \mathrm{E}+05$ & BDL \\
\hline & & AC-1 & sediment & & & & & BDL & $3,20 \mathrm{E}+02$ \\
\hline & & AC-3 & sediment & & & & & $1,90 \mathrm{E}+04$ & $1,20 \mathrm{E}+02$ \\
\hline & & AC-5 & sediment & & & & & BDL & $1,90 \mathrm{E}+03$ \\
\hline & & AC-10 & sediment & & & & & $6,20 \mathrm{E}+04$ & $9,60 \mathrm{E}+02$ \\
\hline
\end{tabular}

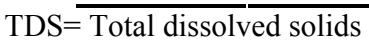

\subsection{Microbial diversity fingerprint}

In the sites studied (Aguas Calientes and Licancabur) DGGE fingerprint, from brine and sediment samples, present higher bacterial than archaeal diversity (data not shown). Those results were also found in other high altitude lakes ${ }^{13,14}$. Between $12-17 \%$ of Licancabur isolated sequences are unclassified at the phylum level, $60-72 \%$ at the genus level. Alpha, beta and gammaproteobacteria phyla were recovered from the Aguas Calientes lake, and Bacteroidetes, Betaproteobacteria and Actinobacteria from the Licancabur summit lake. In addition several sequences related to unidentified ones have also been retrieved. Only one phylogenetic group recovered is common between sites, Betaproteobacteria (Table 4 and 5). Many sequences (100\% in Aguas Calientes samples and $60 \%$ in Licancabur summit lake) presented similarity lower than $95 \%$ with their closest cultured relative. Five of these sequences from the Licancabur samples are related to a previously defined Bacteroidetes cluster from Northern Chile salt flats, Salar de Atacama $(2350 \mathrm{~m})$, Salar de Ascotán $(3990 \mathrm{~m})$ and salar de Huasco $(3800 \mathrm{~m}){ }^{15-17}$, and one more is related to an uncultured Comamonadaceae (Betaproteobacteria) also similar to a sequence isolated from Salar de Huasco ${ }^{17}$. One sequence from Aguas Calientes is related to the isolated from a fresh water lake Chungará $(4520 \mathrm{~m})^{17}$, Chile. The predominant Phylum in Laguna Aguas Calientes seems to be Proteobacteria, but most of the sequences (70\%) are related to unidentified Bacteria and can not be assigned to known phylogenetic group. Microbial community composition in the Licancabur Lake reveals the dominance of Cytophaga-Flavobacteria-Bacteroidetes and Proteobacteria as recently reported in studies performed in Lake Chaka and Lake Quinghai, two athalassohaline lakes located on the Tibetan Plateau (NW China) at an altitude of $3200 \mathrm{~m}^{13,14}$ and in altiplanic wetlands, Salar de Huasco and Salar de Ascotán

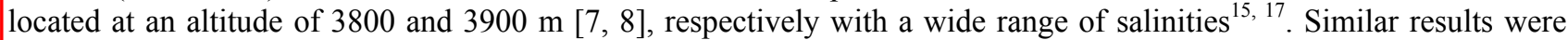
also found by Farias et al in Argentinean High altitude Andean wetlands (unpublished data). These similarities probably reflects common environmental conditions, as water bodies located in the Tibetan Plateau and the Altiplano are athalassohaline and located at high altitude, with similar abiotic conditions including UV-B radiation and negative water balances.

As has been reported in similar environments ${ }^{17}$, the number of phylotypes observed in sediment samples from Aguas Calientes lake (Fig. 3, Table 4) is higher than in water samples.

Those results confirm the observation that, despite the diverse geological settings, physical and chemical properties, only a limited number of bacterial groups predominate ${ }^{14}$ in high altitude lakes studied. Aguas Calientes and Licancabur summit lake (> $5800 \mathrm{~m}$ ), show an even more restricted microbial diversity considering only DGGE results.

Up to now, it was not possible to obtain good archaeal sequences from DGGE bands of Aguas Calientes samples. 


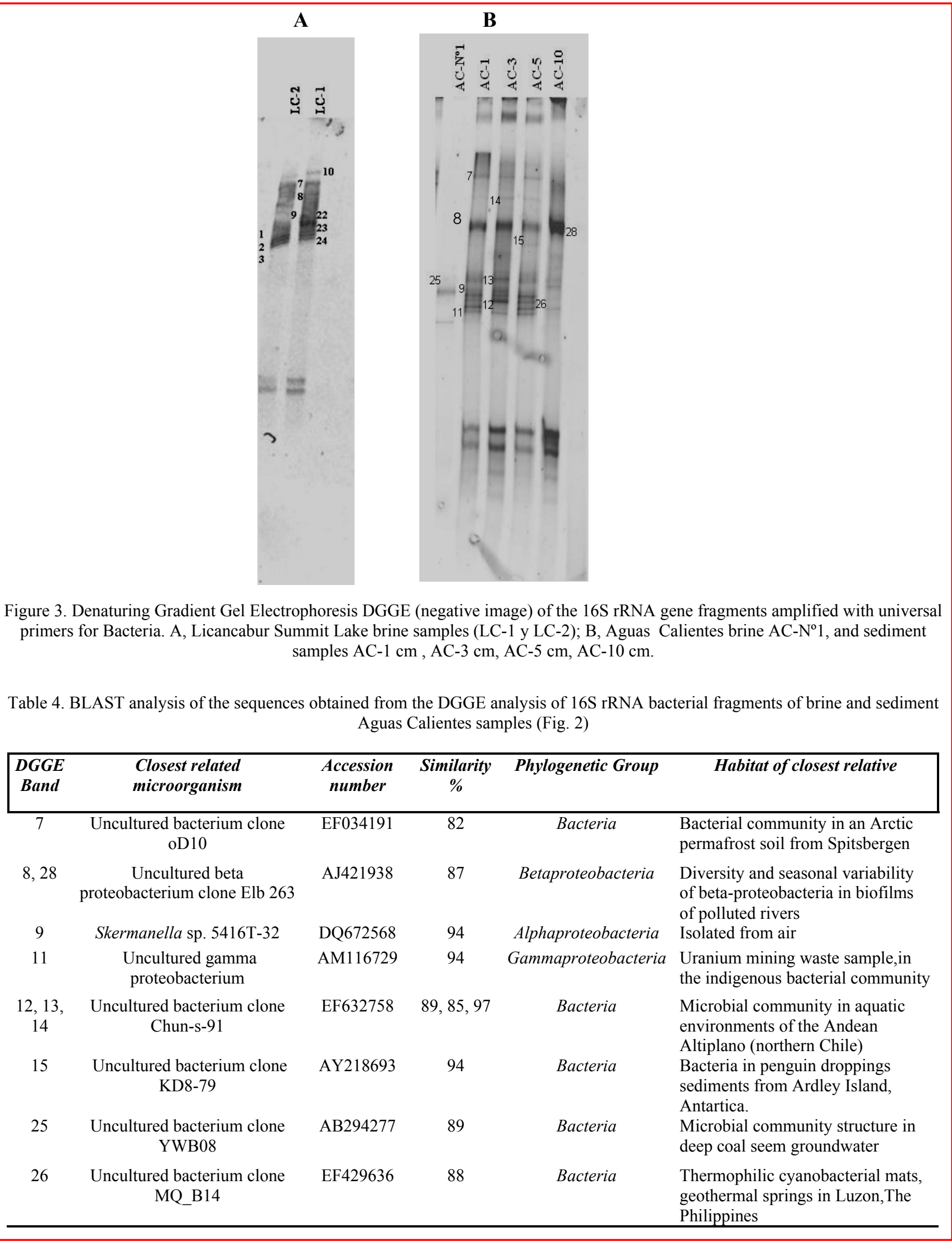




\subsection{Isolates characterization and antimicrobial susceptibility}

Seventeen isolated were found by plating in solid Luria Bertani medium (LB) and R2A media. The colonies were grouped into different morphological types. Most of the isolates were gram Negative and ATB resistant Bacteria. The greatest susceptibility was found to tetracicline.

Phylogenetic identification of the isolated strains was determined by partially sequencing the 16S rRNA genes. Identified sequences are distributed in two bacterial phyla: Firmicutes (2 isolates) represented by Staphylococcus epidermidis strain S09; and Gammaproteobacteria (14 isolates) represented by Pseudomonas sp. Nj-55 and Gammaproteobacterium BT-P-1 (Table 3). Gammaproteobacteria and Firmicutes are usually isolated from these environments like Laguna Verde, Bolivia (4,340 m and Laguna Vilama (4,400 m altitude) and Laguna Azul (4,560 m) in Argentine ${ }^{18}$.

Antibiotic resistance patterns of isolates from Laguna Verde show that both strains where sensitive to kanamycin, rifampicin and nitrofurantoin. However, while one of the strains (LV3) was also sensitive to ampicilin and penicillin, the other one (LV3N) did not show sensitivity regarding those two antibiotics.

Table 5. BLAST analysis of the sequences obtained from the DGGE analysis of 16S rRNA bacterial fragments of brine and sediment Licancabur samples from 2002 and 2003 campaigns (Fig. 2).

\begin{tabular}{|c|c|c|c|c|c|}
\hline Band & $\begin{array}{l}\text { Closest related } \\
\text { microorganism }\end{array}$ & $\begin{array}{l}\text { Accession } \\
\text { number }\end{array}$ & $\begin{array}{c}\text { Similarity } \\
\%\end{array}$ & Phylogenetic Group & $\begin{array}{c}\text { Habitat of closest relative/cultured } \\
\text { physiology }\end{array}$ \\
\hline $\begin{array}{l}2003: \\
5,6\end{array}$ & $\begin{array}{l}\text { Uncultured beta } \\
\text { proteobacterium clone } \\
\operatorname{ccs} \operatorname{lm} 224\end{array}$ & AY133088 & 83,94 & Betaproteobacteria. & TCE-contaminated site \\
\hline 2003:30 & $\begin{array}{l}\text { Delftia acidovorans isolate } \\
\text { As } 3-4\end{array}$ & AY367028 & 96 & Betaproteobacteria. & \\
\hline $2003: 33$ & $\begin{array}{l}\text { Uncultured beta } \\
\text { proteobacterium clone } \\
\text { AGCM38 }\end{array}$ & AF477803 & 93 & Betaproteobacteria. & Aerobic Granules \\
\hline 2003:34 & $\begin{array}{l}\text { Uncultured bacterium clone } \\
\text { CCSD_RK1080_B15 }\end{array}$ & AY820725 & 83 & Bacteria & $\begin{array}{l}\text { Rocks and Fluids From the Chinese } \\
\text { Continental Scientific Drilling in } \\
\text { China }\end{array}$ \\
\hline $\begin{array}{l}2002: \\
1,23\end{array}$ & $\begin{array}{l}\text { Uncultured lake bacterium } \\
\text { P38.3 }\end{array}$ & AY752085 & 94,96 & Bacteria & $\begin{array}{l}\text { Bacterioplankton in two oligo- } \\
\text { mesotrophic lakes }\end{array}$ \\
\hline $\begin{array}{l}2002: 3 \\
24\end{array}$ & $\begin{array}{l}\text { Actinobacterium MWH- } \\
\text { Dar4 }\end{array}$ & ASP565416 & 91,91 & Actinobacteria & $\begin{array}{l}\text { Facultatively anaerobic and } \\
\text { chemoorganotrophic. Optimal } \\
\text { temperature is } 37^{\circ} \mathrm{C}\end{array}$ \\
\hline $\begin{array}{l}2002: 4 \\
5,6,18 \\
20,21\end{array}$ & $\begin{array}{l}\text { Uncultured Flavobacterium } \\
\text { sp. }\end{array}$ & AJ487534 & $\begin{array}{c}96,98,90 \\
97,97,98\end{array}$ & Bacteroidetes & $\begin{array}{l}\text { Bacteroidetes cluster from chilean } \\
\text { salt flats close to Psychrophlexus } \\
\text { genus }\end{array}$ \\
\hline $\begin{array}{l}2002: 7 \\
8\end{array}$ & Bacterium c115 & AB167243 & 90,98 & Bacteria & $\begin{array}{l}\text { Chemostat enrichment from an } \\
\text { aquifer soil as inoculum and phenol } \\
\text { was supplied as sole carbon source }\end{array}$ \\
\hline 2002:9 & $\begin{array}{l}\text { Uncultured } \\
\text { Comamonadaceae } \\
\text { bacterium clone C-14 }\end{array}$ & AF523051 & 91 & Betaproteobacteria & $\begin{array}{l}\text { Non-carbonated natural mineral } \\
\text { water }\end{array}$ \\
\hline 2002:10 & Cyclobacterium sp. & AY259502 & 88 & Bacteroidetes & $\begin{array}{l}\text { Bedrock aquifer contaminated with } \\
\text { chlorinated solvent }\end{array}$ \\
\hline $2002: 15$ & $\begin{array}{l}\text { CFB group bacterium } \\
\text { A0653 }\end{array}$ & AF236016 & 86 & Bacteroidetes & \\
\hline 2002:17 & $\begin{array}{l}\text { Uncultured prokaryote } \\
\text { isolate }\end{array}$ & AY501502 & 85 & $\begin{array}{l}\text { Prokaryotic } \\
\text { environmental }\end{array}$ & $\begin{array}{l}\text { Salt marsh sediments along the East } \\
\text { coast of the United States }\end{array}$ \\
\hline
\end{tabular}


Table 6. Phylogenetic characterization and ATB resistance pattern of the strains isolated from Aguas Calientes samples.

\begin{tabular}{|c|c|c|c|c|c|c|c|c|c|}
\hline & \multirow{2}{*}{ Isolate } & \multirow{2}{*}{ Closest related } & \multirow{2}{*}{$\begin{array}{c}\text { Accesion } \\
\text { number }\end{array}$} & \multirow{2}{*}{$\begin{array}{c}\% \text { 16S rDNA } \\
\text { similarity }\end{array}$} & \multirow{2}{*}{$\mathrm{TE}_{8(\min )}$} & \multicolumn{4}{|c|}{ ATB Resistance } \\
\hline & & & & & & Em & Amp & Tc & $\mathrm{Cm}$ \\
\hline 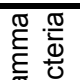 & $\begin{array}{c}\text { BRU-N }^{\circ} 1 \\
\text { (4) }\end{array}$ & Pseudomonas sp. Nj-55 & AM409368 & 99 & 64.3 & + & + & - & + \\
\hline 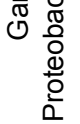 & $\begin{array}{l}\mathrm{BR}-\mathrm{N}^{\circ} 1 \\
\text { (3) }\end{array}$ & $\begin{array}{l}\text { Gamma proteobacterium BT- } \\
\qquad \text { P-1 }\end{array}$ & AY539822 & 99 & 3 & + & + & - & + \\
\hline 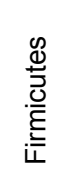 & $\begin{array}{l}\mathrm{AP}-3 \mathrm{~cm} \\
\quad(1)\end{array}$ & $\begin{array}{l}\text { Staphylococcus epidermidis } \\
\text { strain S09 }\end{array}$ & AY741152 & 99 & ND & + & - & + & + \\
\hline
\end{tabular}

(+= Positive growth in presence of the ATB).

\subsection{UV-C resistance}

The percentage of survival versus the UV-C radiation doses is shown in Figure 4. Both isolates analyzed show further inhibition with larger doses of UV-C radiation. Significant differences in survival after UV-C irradiation were observed. Higher survival was observed in Pseudomonas sp. compared with the other gamma Proteobacteria, both isolated from brine samples. Similar UV-C resistance results were observed with Proteobacteria isolates form Lake Chaka ${ }^{14}$. Tested strains show no recovery of cells number after $120 \mathrm{~min}$ exposure under dark conditions. Similar low capacity for recovery have been found in the Pseudomonas sp. strain MF8 isolated from Laguna Pozuelos, Argentina (3600 m) ${ }^{19}$.

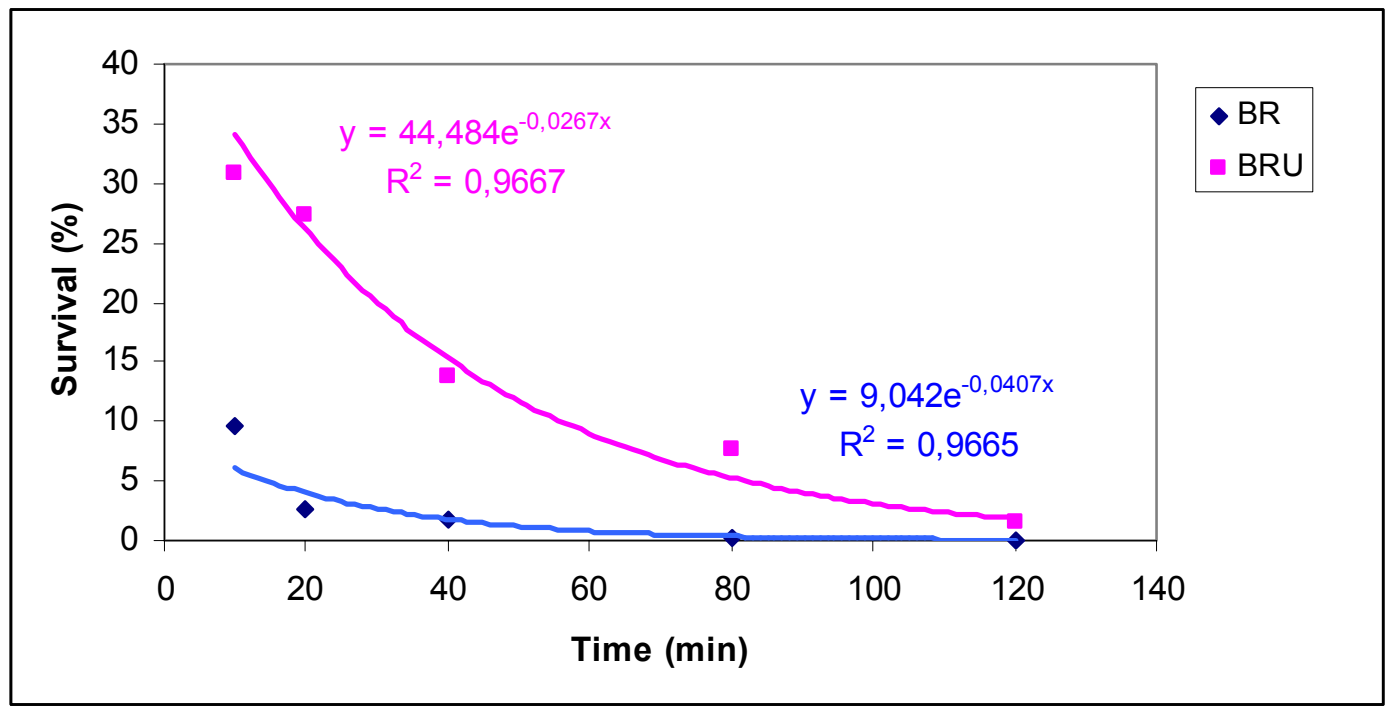

Figure 4. UV-C resistance of two isolates from Aguas Calientes $(5,930 \mathrm{~m})$ vs. exposure time.

These results would confirm that in extreme environments like high altitude wetlands there could be a correlation of multiresistances to UV radiation ${ }^{18}$. The presence of widespread resistance to ATB was unexpected in this pristine and 
oligotrophic environment, where it is not predictable to find selection pressure for ATB resistances. Recently have been demonstrated in some isolates that the presence of ATB resistances would not be induced by mutagenesis ${ }^{18}$, one of the hypothesis proposed to explain the multiresistances relation to UV radiation.

\section{CONCLUSIONS}

Microbial diversity in high altitude andean lakes analyzed by a culture independent technique shows the presence of a limited number of bacterial groups and a high percentage of sequences that can not be assigned to any known phylogenetic group.

The isolates obtained from Aguas Calientes and Licancabur summit lake [8] belong to the Gammaproteobacteria and Firmicutes group. They denoted high ATB resistance.

Significant differences in survival after UV-C irradiation were observed. Higher survival was observed in Pseudomonas sp. compared with the other gammaproteobacteria, both isolated from brine samples.

More experiments should be performed to evaluate tendencies and to analyze DNA repair systems used.

\section{ACKNOWLEDGMENTS}

We thank Iván Balic for laboratory assistance, Fondecyt project 1030441 and Grant "BIOARSENICO" from Fundación BBVA.

\section{REFERENCES}

[1] Cabrol, N.A., E.A. Grin, C.P. McKay, I. Friedmann, G.C. Diaz, C. Demergasso, K. Kisse, I. Grigorszky, R.O. Friedmann, M.S. Murbach, A. Hock, D.A. Fike, C. Tambley, L. Escudero, E. deVore, and B. H.Grigsby: "First results of the expedition to the highest lake on earth: studying a martian paleolake in bolivia and the survival strategies developed by living organisms." 34 th Lun. Plan. Sci. Conf., p. Abstract number 1140. Houston, Texas, 2003.

[2] Helbling, E.W., M.E. Farias, M.V.F. Zenoff, and V.E. Villafane, "In situ responses of phytoplankton from the subtropical Lake La Angostura (Tucuman, Argentina) in relation to solar ultraviolet radiation exposure and mixing conditions", Hydrobiologia, Vol.559, 123-134, 2006.

[3] Cockell, C.S. and L.J. Rothschild, "The effects of UV radiation A and B on diurnal variation in photosynthesis in three taxonomically and ecologically diverse microbial mats", Photochemistry and Photobiology, Vol.69, 203$210,1999$.

[4] Vinebrooke, R.D. and P.R. Leavitt, "Effects of Ultraviolet Radiation on Periphyton in an Alpine Lake", Limnology and Oceanography, Vol.41, 1035-1040, 1996.

[5] Vincent, W., W. Wurtsbaugh, C. Vincent, and P. Richerson, "Seasonal dynamics of nutrient limitation in a tropical high-altitude lake (Lake Titicaca, Perú-Bolivia): application of physiological bioassays." Limnology \& Oceanography, Vol.29, 540-552, 1984.

[6] Demergasso, C., J. Blamey, L. Escudero, G. Chong, E.O. Casamayor, N. Cabrol, E.A. Grin, A. Hock, A. Kiss, G. Borics, K. Kiss, E. Acs, G. Kovacs, R. Sivila, J. Zambrana, M. Liberman, M.S. Coro, C. Tambley, V. Gaete, R.L. Morris, B. Grigsby, R. Fitzpatrick, and G.Hovde: "Characterization of two microbial isolates from andean lakes in Bolivia." Lun. Plan. Sci. Conf. 35, p. Abstract No. 1534. League City, Texas, 2004. 
[7] Schauer, M., R. Massana, and C. Pedrós-Alió, "Spatial differences in bacterioplankton composition along the Catalan coast (NW Mediterranean) assessed by molecular fingerprinting", Fems Microbiol Ecol, Vol.33, 51-59, 2000

[8] Muyzer, G. and K. Smalla, "Application of denaturing gradient gel electrophoresis (DGGE) and temperature gradient gel electrophoresis (TGGE) in microbial ecology", Antonie Van Leeuwenhoek, Vol.73, 127-41, 1998.

[9] Raskin, L., J.M. Stromley, B.E. Rittmann, and D.A. Stahl, "Group-specific 16S rRNA hybridization probes to describe natural communities of methanogens", Appl Environ Microbiol, Vol.60, 1232-40, 1994.

[10] Stahl, D. and R. Amann, "Development and application of nucleic acid probes", in Nucleic acid techniques in bacterial systematic, E. Stackebrandt and M. Goodfellow eds., pp. 25-248, Wiley, New York, 1991.

[11] Casamayor, E., G. Muyzer, and C. Pedrós-Alió, "Composition and temporal dynamics of planktonic archaeal assemblages from anaerobic sulfurous environments studied by 16S rDNA Denaturing Gradient Gel Electrophoresis and sequencing." Aquat Microb Ecol, Vol.25, 237-246, 2001.

[12] Cabrol, N.A., E.A. Grin, K.T. Kiss, E. Ács, I. Grigorszky, K. Szabò, B. Tóth, D.A. Fike, A.N. Hock, C. Demergasso, L. Escudero, G. Chong, P. Galleguillos, B.H. Grigsby, J.Z. Román, and C.P. McKay, The Edge of Life in Extreme Lakes. 2004.

[13] Dong, H., G. Zhang, H. Jiang, B. Yu, L.R. Chapman, C.R. Lucas, and M.W. Fields, "Microbial diversity in sediments of saline Qinghai Lake, China: linking geochemical controls to microbial ecology." Microbiol Ecol, Vol.51, 65-82, 2006.

[14] Jiang, H., H. Dong, G. Zhang, B. Yu, L. Chapman, and M. Fields, "Microbial diversity in water and sediment of Lake Chaka, an athalassohaline lake in northwestern China." Appl Environ Microbiol, Vol.72, 3832-3845, 2006.

[15] Demergasso, C., E.O. Casamayor, G. Chong, P. Galleguillos, L. Escudero, and C. Pedrós-Alió, "Distribution of prokaryotic genetic diversity in athalassohaline lakes of the Atacama Desert, Northern Chile." FEMS Microbiol Ecol, Vol.48, 57-69, 2004.

[16] Demergasso, C.S., Prospección de actividad microbiológica de interés biotecnológico en hábitats acuáticos del Desierto de Atacama PHD thesis thesis. Cátedra de Microbiología, Facultad de Farmacia y Bioquímica. Buenos Aires: Universidad de Buenos Aires. 272 pp. 2004.

[17] Dorador, C., Microbial communities in high altitude altiplanic wetlands in northern Chile: phylogeny, diversity and function. PhD thesis. Max PlancK Institut für Evolutionsbiologie. Kiel: Christian-Albrechts-Universität. 170 pp. 2007.

[18] Dib, J., J. Motok, V.F. Zenoff, O. Ordoñez, and M.E. Farías, "Occurrence of resistance to antibiotics, UV-B and arsenic in bacteria isolated from extreme environments in high altitude (above $4400 \mathrm{~m}$ ) Andean wetlands." in press.

[19] Fernandez Zenoff, V., F. Sineriz, and M.E. Farias, "Diverse responses to UV-B radiation and repair mechanisms of bacteria isolated from high-altitude aquatic environments", Appl Environ Microbiol, Vol.72, 7857-63, 2006. 